\title{
Map of Changes in Abnormal Return and Trading Volume Activity: Reviewing the Effect of Ramadhan in Indonesia
}

\author{
Endang Tri Widyarti, Sugeng Wahyudi, Hersugondo Hersugondo* \\ Department of Management, Faculty of Economic and Business, Diponegoro University, Indonesia
}

Received July 17, 2021; Revised August 18, 2021; Accepted September 21, 2021

\section{Cite This Paper in the following Citation Styles}

(a): [1] Endang Tri Widyarti, Sugeng Wahyudi, Hersugondo Hersugondo , "Map of Changes in Abnormal Return and Trading Volume Activity: Reviewing the Effect of Ramadhan in Indonesia," Universal Journal of Accounting and Finance, Vol. 9, No. 5, pp. 1093 - 1102, 2021. DOI: 10.13189/ujaf.2021.090519.

(b): Endang Tri Widyarti, Sugeng Wahyudi, Hersugondo Hersugondo (2021). Map of Changes in Abnormal Return and Trading Volume Activity: Reviewing the Effect of Ramadhan in Indonesia. Universal Journal of Accounting and Finance, 9(5), 1093 - 1102. DOI: 10.13189/ujaf.2021.090519.

Copyright $\odot 2021$ by authors, all rights reserved. Authors agree that this article remains permanently open access under the terms of the Creative Commons Attribution License 4.0 International License

\begin{abstract}
Investor assessment of information on the effect of Ramadhan on stock return and trading volume company activities in the capital market is an important phenomenon that always occurs. The purpose of this study was to analyze average abnormal returns and average trading volume activities of stocks before and after the announcement the effect Ramadhan as National Non-Natural Disaster. The method used was an event study with a sample of companies listed in the LQ45, JII, SRI KEHATI, and PEFINDO Indexes. Observations of the 30-day Ramadan event were carried out from April 23 to March 24, 2021, in the month of Sha'ban - syawwal, using 15 samples obtained from IDX (Indonesian Stock Exchange) data. The analytical tool used was regression supported by the SPSS application. The results of the study showed that the Abnormal Returns (AR) was significantly different before (Sya'ban) and after the month of Ramadan (Syawal) for companies on the Indonesia Stock Exchange in 2021, indicating a consistent AR reaction to the Ramadhan Effect. Meanwhile, Trading Volume Activities (TVA) didn't differ significantly before (Sya'ban) and after the month Ramadan (Syawal) at companies on Indonesia Stock Exchanges in 2021. This study updates previous research by including the effect of Ramadan as a research test variable.
\end{abstract}

Keywords Abnormal Return, Trading Volume Activity, Ramadhan Effects, Stock Market

\section{Introduction}

As an economic tool, the capital market is affected by environment, both economically and non-economically [1]. The effect of the microeconomic environment, such as company performance, changes in company strategy, announcements of financial statements, or company dividends will always be responded by market participants in the capital market [2]. The changing environment makes macroeconomic conditions, such as changes in interest rate, savings, deposit, rupiah exchange rate, inflation, and various regulation as well as deregulations issued by the government, which affect price fluctuations and the number of capital market transactions [3]. Even the non-economic environment, such as the announcement of certified awards and other events, intensely influences the stock price and trading volume [4]. In addition, the pronouncement of certified awards to capital market institutions will increase investor confidence so that they will get a positive response from market participants [5].

Market participants will consider any information related to the ongoing event or condition. Generally, the information needed by investors can come from the internal and external conditions of the company (issuer). Efficient capital market will respond quickly to all 
relevant informations, which is indicated by changes in stock price that exceed normal conditions, leading to abnormal returns [6]. The information stored by investors will change to the daily trading volume fluctuations and the frequency of transactions (Nicola, M., et al, 2021). This fluctuation is caused by some personal information displayed through the transaction process, not because of the spread that increases public information (Antoniou, C., et al, 2013a).

According to Blasco, N., Corredor, P., Ferreruela, S., (2012), the test information content aims to examine responses to the announcement. If the pronouncement containing information, the market is expected to respond promptly. The market reaction indicates that there is a change in the price of the relevant security. This response can be measured using returns as the value or utility of changes in the abnormal returns price [9]. If using abnormal returns, the announcement containing the information will make an exception back to the market [2]. Otherwise, uninformed content will not provide an unusual market advantage [10].

In addition to using excess profits, the market capital response to information can be seen from the movement parameters of the volume of trading activity. If investors judge an event to contain information, the event will lead to transact on decisions outside of regular transaction decisions. Białkowski, et al, (2013) stated that market reaction is signal about event information where price changes will affect value of the company and number trading shares that occur. Investors can also observe transaction volume information related to stock prices. Stocks traded high will yield considerable stock returns [12].

Various unpredictable information entering the capital market influences stock prices [13]. In 1953, Maurice Kendall stated that the stock price model was unpredictable, and it seemed that stock prices were random walk. Initially, the results of Kendall's disturbed the thinking of financial economists, as the real stock market was influenced by market psychology or "animal spirit" so the rules were illogical [4]. Finally, economists understood and explained the results of the Kendall's findings. As a result, the reaction in the capital market is difficult to predict because the market will only move when information comes [14]. Therefore, when the capital market moves based on available information, the capital market can provide an overview of the actual economic situation, not based on predictable patterns. The consequences are that investors do not get consistent profits when using price information in the past [9].

According to (Białkowski et al, 2012), research on impact of certain events abnormal return and trading volume activity is carried out using the event study method. This event study was conducted to observe the market share price at the time of the event to identify whether there was a return on investment received by investors. As a result, investors can get unusual investment returns as a result of these events. The sensitivity level of capital market dynamics is influenced by macro factors, including economic and non-economic factors.

The Ramadhan effect is market anomaly, seasonal anomaly, showing the difference in the average monthly returns of Ramadan compared to other months other than Ramadan [15]. The month of Ramadan occurs on a different day and month each year following the advertising calendar. During Ramadan, Muslims fast for one month, yet Gavriilidis, Kallinterakis, \& Tsalavoutas, 2016 argued that consumption of food and drink during Ramadan increases significantly. According to Białkowski et al., 2013, changes in consumers' behavior in the months of Ramadan increase people's consumption levels, especially the amount of food and beverage consumption increase two to three times.

The reason for selecting the Ramadhan Effect event as the object of research is that the Ramadan event will affect changes in consumer behavior that increase during the month of Ramadhan (Al-Hajieh, Redhead, Rodgers, 2011), especially food and beverage products (Antoniou, C., Doukas, J.A., Subrahmanyam, 2013). The changes will affect the world economy, as there are demands for any product (Nicola, M., et al, 2021). The Ramadhan effect, shown by the abnormal return and the volume of activity transactions, is obtained by investors [9]. According to Kumar, A., Page, J. K., \& Spalt, 2011 the market reaction can be measured by the presence of abnormal returns. The TVA measure near the event is the means that is used to determine whether the event contains information that results in a higher share demand level than the share issuance demand level, resulting in increased trading volume [18]. The phenomenon of the stock trading volume of the Ramdhan Securities comes from the positive aspect of the ongoing transaction [13].

A time limit is needed when analyzing the impact of an event to measure the abnormal returns that can occur before and after the event, known as the window period. Determination of the target window period is done to ascertain market conditions before Ramadan, market conditions during Ramadan, and market conditions after Ramadan.

Białkowski et al, 2012 investigated stock return during Ramadhan for Muslim-majority country during 1989-2007. Sample were countries whose stocks market index was ready in Morgan Stanley Capital Internationals (MSCI) on Datastream, where proportion of Muslim populations data is more than $50 \%$. Data on populations and religious divisions were from Central Intelligence World Fact Book (CIA) (2009). The final sample consisted of 14 countries inhabited by nearly 695 million peoples. For each country, date on which the daily observation on MSCI index were ready to determine the number occurrences. Itwas worth mentioning event study 
analysis carried out in next section required at least 200 observations before first Ramadhan began the benchmark model returns could be estimated. Guided by this consideration, the study concluded a sample of 129 event. Result showed stock return during Ramadhan are significant higher and less volatile compared to rest of years. Not apparent decline on market liquidity is noted. This finding is consistent with the notion Ramadhan has positive impact on investor psychologies.

Białkowski et al., 2012 also examined whether mutual fund manager who invested in Turkish stock could benefit from Ramadhan effect. Study used daily data on Turkish domestic mutual fund and foreign mutual fund by focusing in a Turkish Equity investment from January 2000 for March 2011. According Takasbank, its settlements and the Custodial bank of Istanbul Stock Exchanges, 2000 marked beginning of systematic and recorded Turkish mutual fund data were reliable. Since interest of this paper lies in Turkish stock market, this study collected information on type A Mutual Fund, which legally require investing at least $25 \%$ their portfolio holding in equities issue by domestic companies. Domestic samples were obtained from Takasbank consisted 166 open-ended mutual funds. Database of Takasbank contained a classification of mutual fund types as well as days of total net asset, the net assets value of shares, and the details of fund asset allocation. According their investment objectives, 27 of 166 mutual funds are classify as equity mutual funds, 27 mixed mutual fund, 27 variables mutual fund, 34 index mutual fund, and 11 private mutual funds. The study finds that performance domestics risk-adjusted institutional fund, hybrid fund, and foreign Turkish equity fund is substantially higher during Ramadhan compared to year. In contrast, domestic index fund failed deliver higher abnormal returns as they were affected by the increased inflow of money during Ramadhan.

Al-Hajieh et al, 2011 examine whether the effect of Ramadan on capital market was factual, as it appeared in the anomaly effect of positive calendar in the Middle East Islamic Stock Market during 1992-2007. For countries for which data sets were available, the whole studied period covered January 1, 1992, to 31th December 2007. Strong evidence finds that there is significant and positive calendar effect respecting entire period of Ramadhan in most country, and it was being argued that could be attribute investors' moods than positive or sentiments. The results also show that although overall Ramadhan effect is both positively and statistically significant for most country, associated benefits are only large enough outweigh transaction cost and provide basis of profitable trading strategic in one market.

Using the Stochastic Dominance (SD) approach Al-Khazali, (2014), this paper reviews effects of Ramadhan on stock returns 15 Muslim countries and portfolios. This study was motivated by favored statistical attribute the SD analyzed. In particular, it does not require a normal distribution assumed return, and it impose some limitations on the risk-return and trade-off preference. To capture the effects of various economic event and condition, we examined effects of Ramadhan over entire samples and five sub-periods from January 1989 to December 2012 (1989-1995, 1996-2000, 2001-2006, 2007-2012, and 1989-2012). The sub-period was selected to match the previous study and allow analyzed over various period during specific structural change may occurred, such during 2007-2008 financial crisis. Result showed that effect of Ramadhan took place in most of the Muslim countries during period 1996-2000, 2001-200, and in the sub-periods 1995-2007. However, the amount decreased during the period of the global financial crisis (2007-2012).

Gavriilidis et al., 2016, using samples from seven Muslim-majority countries, examined whether positive moods document during Ramadhan are translated higher returns compared those on non-Ramadhan day. Result was that significant returns occurred during Ramadhan in most of sample market. The data observed were data of closing prices and trading volumes of all common shares listed in equity market in Bangladesh, Egypt, Indonesian, Malaysia, Morocco, Pakistan, and Turkey. Seven markets operate predominantly Muslim country whose data are available since early 1990s. Allowed to have long windows of time to test relationship files between herd and Ramadhan. Therefore, data related to the start date each market can be traced back to period 1990-1994, while end date is 28/02/2014. Moreover, returns appeared to be much stronger during Ramadhan than outside of Ramadan, in which the significance was manifested. Overall, significance of herding inside/out of Ramadhan suggests some variation in degree across market concerning variable reflecting conditions, both domestic (market return; market volume) and international (US market return; US investor sentiments; global finance crises) conditions.

Sonjaya \& Wahyudi, 2016 and other researchers who conducted an empirical test of the efficient market hypothesis (EMH) found inconclusive results; some supported it, while others did not find clear evidence for it. One result weakens EMH is study of anomalies such as Ramadhan Effect; in fact, anomalous study contradicts recent studies which show evidence of weakening even the disappearance effect of anomaly. Study examined persistent effect Ramadhan on stock return in 10 Muslim-majority countries. This study uses stock market index from Morgan Stanley Capital International (MSCI) Data stream. The sample country must have Muslim population more than 50\% (according to CIA World Factbook 2013). Ten countries included in study were Bahrain, Indonesian, Jordan, Malaysia, Morocco, Kuwait, Oman, Qatar, Saudi Arabia, and Tunisia. Study periods covered 139 Ramadan events during period 1989-2013. 
Sample period was further divided into five sub-period of observing the persistence of Ramadhan effect: 1989 to 1993, 1994 to 1998,1999 to 2003, 2004 to 2008, and 2009 to 2013. Determination of beginning and end Ramadan in Gregorian calendar based on information from country's official website stating official start end Ramadhan. Data from MSCI Index is denominated in USD, therefore there isn't stock price bias due to inflation in every country. We have found that Ramadhan effect exists, but it does not persistent. Finding consistent with one from efficient market form test, shows that markets of 10 Muslim-majority country is inefficient. While the economic crisis is considered influence factor, effects of Ramadhan are still there.

Based on the differences in the economic and socio-religious activities of the community during Ramadan, there are differences between the efficient market theory and the reality that occurs in the capital market, called market abnormalities. Meanwhile, research findings are still limited regarding the reaction of the Indonesian Capital Market to the Effect of Ramadan in Indonesia, which is one of the countries with a majority Muslim population. As there is a research gap from previous research, the research with the title proposed is Reaction Abnormal Return and Trading Volume Activity on Ramadan Effects (Studies on LQ45 Index, JII, PEFINDO, SRI -KEHATI listed on the Indonesia Stock Exchange 2019-2021).

\section{Literature Reviews}

\subsection{Signaling Theories}

Signaling theories Tantatape, (2014) in this study is related to the existence of the information, namely signals or indications of abnormal returns and trading volume of the company's stock activities to investors and other market participants [10]. With these instructions, investors and market participants can do this by making decisions and attitudes before and after an event.

Signaling theory stems from the asymmetric information in which specified economic transaction inequality in accessing information normal market exchanging good and service occurs [15]. Kumar, A., Page, J. K., \& Spalt, 2011 suggested that both parties could obtain asymmetric information signals from all parties, which would reveal some relevant information to the other party.

The signaling principle tells that every action contains information due to the presence of asymmetric information [13]. Asymmetry information is a condition for one party to have more information than the other party [1]. For example, company management has more information than investors in capital market. The level of asymmetric information ranges from very high to very low [2]. Therefore, the condition and status of the company must be considered in the form of a gradual company life cycle in context of user report that provide better understanding of stages of the company's life cycle. The finance department can determine which accounting information should be used [2].

\subsection{Overreaction Hypothesis}

Market overreaction will occur when buying and selling stocks where investors will base their decisions on their emotions, experiences, and intuition [15]. Investors can capitalize on needed news or reducing conflicting outcomes from unproven and unwanted stories by responding quickly to new information [21]. In general, investors tend to overreact to extraordinary events and the latest information to ignore old information [1].

\subsection{Market Efficiency}

According to Kumar, Page, \& Spalt, (2011), there are three types of information forming market efficiency: past information, currently published information, and private information. They are

\section{Weak Form Market Efficiency}

If the price comes from the market, the market is said to be in a state of inefficiency. Security fully reflects the information in the past. Past information is information that has occurred.

\section{Semi-Strong Form Market Efficiency}

A market is a form of semi-strong market efficiency if price of security can full reflect all publish information (available information) by include the information contain the financial statement of listed companies.

\section{Strong Form Market Efficiency}

If prices rise, the market is considered an important form of market efficiency. Securities fully reflect all available information, including personal information.

In this study, the efficiency of the semi-strong form was tested. If an abnormal return occurs, the market must react quickly to absorb the abnormal return and transfer it to a new equilibrium price. The efficiency of the semi-strong form of market lies only the published information.

\subsection{Abnormal Return}

Abnormal return is the actual income gain that occurs when regular income is the expected profit income. In terms of profit, it will be positive if the projected profit is higher than the profit that occurs. Meanwhile, the profit will be negative if the expected profit is smaller than the actual profit [23].

Abnormal returns will analyze abnormal returns from securities that may occur before and after the announcement of an event. Excess revenue is the gain on 
actual revenue that occurs on normal returns; therefore, abnormal returns occur.

\subsection{Trading Volume Activity}

Transaction volume is a part of technological analysis [21]. Mass trading activity on the exchange will be interpreted as sign that market will improve [24]. An increase in stock trading volume is accompanied by an increase in price, which is symptom a stronger bullish [25]. Investors can use the trading volume of shares to check whether the shares purchased are shared that are actively traded in market, as stocks that are active traded must have a large trading volume of trading shares and stocks that have a large trading volume will generate considerable returns (Al-Hajieh et al, 2011).

Changes volume of trading in the capital market indicate that stock trading activities communicate and reflect investors' investment decisions [2]. According to Wang, (2013), TVA can be used to see the capital market changes in the volume of trading transactions through parameter information. The results of the TVA calculation reflect transactions and issued within certain period. TVA method can also be used to test the weak form efficiency market hypothesis [1]. The speed of reaction that occurs between events and their effect on stock prices on the exchange depends on market forces. The more efficient the market, the faster the information is manifested in the same price [15].

\section{Variables and Hypothesis Development}

\subsection{Effect of Ramadan Effect Variables and Abnormal Return}

According to signal theory, the principle of signaling may serve as a guide for investors that every action contains information [19]. This theory stems from the idea of information asymmetry, which explains that in a given economic transaction, there is information difference in the normal market for goods and services [21]. In context of event research, this is observation of stock prices in capital market to find out whether they are abnormal returns [2]. The theory of signals that shareholders occurs because of certain events, meaning each event must contain content affect market (Al-Hajieh et al, 2011).

The effect Ramadhan as event was presumed contain information could influence the market. Market reaction was represented changes stock prices measured in terms of abnormal returns. If the exception report was use, it could be said that the announcement had the content that would provide abnormal returns for the market.

This theory was in line research conducted (Al-Hajieh et al, 2011), [1], and [24], [16], [5], [27], (Calomiris, C. W., Love, I., \& Peria, 2012), showing that there is a difference in average return of exceptions before-after event.

Based on description, the hypotheses in this study are as follows.

H1: Change the average abnormal return before after event the Ramadhan effect.

\subsection{Effect of Ramadan Effect Variables and Trading Volume Activity}

Transaction volume is a part of technology analysis [19]. Mass trading activity on the exchange will interpreted as sign that market will improve [29]. An increase stock price is symptom of a stronger bullished condition (Antoniou, C., Doukas, J.A., Subrahmanyam, 2013). Trading Volume Activity is a signal of the reaction of the market to the event (Summers, B., Duxbury, D., 2012).

The market reactions were not only indicated by changing stock price as reflected in abnormal return, but also by changing the volume of the trading activity concerned. TVA could be used to see whether the disclosure of individual investors of an event would result in changes in the capital market. If investors interpreted information as a positive signal, then the demand for shares would be high so that TVA would increase. On the other hand, if investors interpreted information as a negative signal, then the demand for shares would be low and the TVA would fall.

This theory was in line with research conduct by Białkowski et al, (2013), Reilly, F. K., \& Brown, (2012), and Pantzalis \& Ucar, (2014), Basel, (2013), Mo et al., (2019), Kumar, A., Page, J. K., \& Spalt, (2011), Mustafa, (2011), shows that there is a difference in average return of exceptions before-after event. Based on above formulation, hypothesis in this study is follow.

$\mathrm{H} 2$ : Difference in average trading volume activity before-after Ramadan Effect.

\section{Conceptual Framework}

The reaction of the capital market to the events of Ramadan was the concept that underlay this research. Capital market reaction was measured by changes in average abnormal return and trading volume activity. 


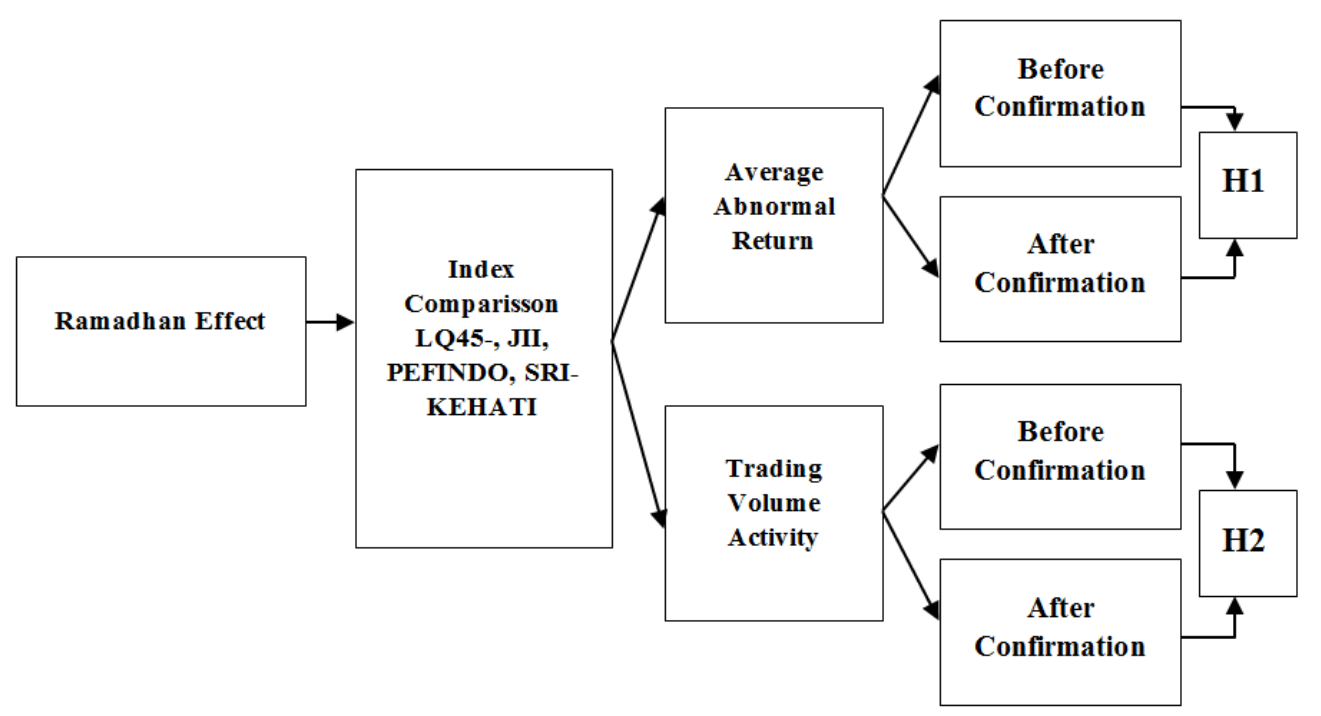

Figure 1. Conceptual Framework

The new equilibrium price was created by the speed with which a market reacts to information. Investors' view of the economy in the future is seen from the market reaction to information on an event related to government policy [35].

Investors will immediately analyze the impact of the Ramadan effect by observing trade volume activity on stock exchange floor. Investors with private information could perform analysis quickly. According to Aguilera, (2017), the volume of stock trading is influenced by the level of activity of the shares traded.

\section{Methodology}

This study used secondary data obtained from institutions that have a relationship with the problems observed. The samples were data comparisons of companies listed in the LQ45 index, the JII index, the PEFINDO index, and the SRI-KEHATI index. The observation period was the 30-day Ramadan event, which started on April 23-March 24, 2021. The window period was chosen to determine the impact affecting stock returns from the Ramadan Effect factor. The Data are collected from Inonesian Stock Exhange (IDX).

This method was applied to examine the stock price and stock volume changes of the pandemic-affected companies on a daily event basis. The study used a non-linear dynamic model to find out and estimate expected stock return and changes in volume of trading shares that corresponded to return if the event period had not been taken. The market model was estimated using the Empirical Specification and assumed a stable linear relationship between market returns and individual stock returns. To test the research hypotheses and investigate the relationship between the pandemic abnormal returns and trade volume activity, the study used a regression model Al-Khazali, (2014) as follows

$$
\text { CSADt }=\alpha 0+\alpha 1(r m, t)+\alpha 2 r 2 m, t+\varepsilon t
$$

Notes :

$r m, t:$ market return at time $\mathrm{t}$

$\alpha t$ : information asymetry at time $\mathrm{t}$

$\varepsilon t$ : residual error. The absolute value of this residual error is used as proxy of information asymetry (AI) at time $\mathrm{t}$

Where CSAD is cross sectional absolute deviations of the calculated returns. This study estimated the parameter using the company's daily records in the LQ45 index, JII index, SRI-KEHATI index, and PEFINDO index as registered independent variables during the estimation period. Data are collected from Indonesian Stock Exchange (IDX). The non-linear dynamic method following Al-Khazali, (2014) and the regression to estimate CAR and CATVA were used to explain the determination of the stock market reaction to the Ramadhan Effect. The impact of various factors describing events, company characteristics, and markets after 1,2, 3 events can be determined using the following regression

$$
\begin{aligned}
C S A D t=\alpha 0 & +\alpha 1 D|r m, t|+\alpha 2(1-D)|r m, t| \\
& +\alpha 3 D r m 2, t+\alpha 4(1-D) r 2 m, t \\
& +\varepsilon t
\end{aligned}
$$

Hypotheses were tested using the normality test. Normality test is used to determine whether data are normally distribute or not, while statistical tests with hypotheses were carried out using the Kolmogorov-Smirnov test [34], as follows

a) If p-value $\geq \alpha$, then $\mathrm{H} 1$ is accepted.

Abnormal stock returns before and after the announcement of the month of Ramadan are normally distributed.

b) If p-value $\leq \alpha$, then $\mathrm{H} 1$ is accepted.

Abnormal stock returns before and after the announcement of the month of Ramadan are not normally distributed. 
c) If p-value $\geq \alpha$, then $\mathrm{H} 1$ is accepted.

Trade volume activity of stocks before-after announcement the month of Ramadan is normally distributed.

d) If $p$-value $\leq \alpha$, then $\mathrm{H} 2$ is accepted.

Trade volume activity of stocks before- after the announcement the month of Ramadan is not normally distributed.

\subsection{Research Gap}

This study updates previous research by including the effect of Ramadan as a research test variable. The Ramadan effect is a market anomaly, i.e., a seasonal anomaly, showing the difference in the average monthly return of Ramadan between other months and Ramadan. This study examines stock prices and changes in the stock volume of companies affected by the pandemic using daily event studies. The study uses a non-linear dynamic model to analyze and estimate the expected stock returns and changes in the volume of trading shares that correspond to returns if the event period has not been taken by doing data normality testing and hypothesis testing with return variables and trading volume activity pre-post-Ramadan.

This study updates research (Al-Khazali, 2014) which uses a non-linear dynamic method with regression to estimate CAR and CATVA to explain determination stock market reactions to the Ramadhan Effect. In contrast to research (Al-Hajieh et al, 2011), (Kumar, A, Page, J. K., \& Spalt, 2011), and (Summers, B., Duxbury, D., 2012), (Gavriilidis et al, 2016), [5], (Białkowski et al, 2012), (Calomiris, C. W., Love, I., \& Peria, 2012), which uses signal theory to show there is a different in the average returns of exceptions before-after event.

\section{Result and Discussion}

The population used in study were all company listed on Indonesia Stock Exchange (IDX).

\subsection{Data Normality Test}

\section{1) Abnormal Return}

Table 4.1. Normality Test Results of AR

\begin{tabular}{|c|c|c|}
\hline \multirow{2}{*}{ Statistik } & \multicolumn{2}{|c|}{$\mathbf{2 0 2 1}$} \\
\cline { 2 - 3 } & Sya'ban & Syawwal \\
\hline $\mathrm{N}$ & 15 & 15 \\
\hline Kolmogrov-Smirnov Z & 0.46 & 0.39 \\
\hline Asymp Sig (2-Tailed) & 0.98 & 1.00 \\
\hline Note & Normal & Normal \\
\hline
\end{tabular}

Table 4.1 shows that:
1. The value of the normality test of the Abnormal Return during the month of Sha'ban 2021, in the Kolmogorov-Smirnov $\mathrm{Z}$ column, is 0.46 and is 0.98 for the Asymp column Sig (2-tailed). This value is great than $0.05(>0.05)$; therefore, the abnormal return during the month of Sha'ban 2021 meets the assumption of normality, or the data has been normally distributed.

2. The results of the normality test for Abnormal Return in Shawwal 2021, the Kolmogorov-Smirnov Z column obtained a value of 0.39 and for the Asymp column. Sig. (2-tailed) obtained a value of 1.00 . This value is greater than $0.05(>0.05)$, which can be concluded that the Abnormal Return in Shawwal 2021 has met the assumption of normality or the data has been normally distributed.

\section{2) Trading Volume Activity}

Table 4.2. Normality Test Results of TVA

\begin{tabular}{|c|c|c|}
\hline \multirow{2}{*}{ Statistic } & \multicolumn{2}{|c|}{$\mathbf{2 0 2 1}$} \\
\cline { 2 - 3 } & Sya'ban & Syawwal \\
\hline $\mathrm{N}$ & 15 & 15 \\
\hline Kolmogrov-Smirnov Z & 1.15 & 1.09 \\
\hline Asymp Sig (2-Tailed) & 0.14 & 0.18 \\
\hline Keterangan & Normal & Normal \\
\hline
\end{tabular}

Table 4.2 shows that:

1. The value of the normality test of Trading Volume Activity in month of Sha'ban 2021, in Kolmogorov-Smirnov $\mathrm{Z}$ column, is 1.15 and for the Asymp column. Sig. (2-tailed) obtained a value of 0.14 . This value is greater than $0.05(>0.05)$; therefore, the Trading Volume Activity in month of Sha'ban in 2021 meets assumption of normality, or the data has been normally distributed.

2. The value of the normality test of the Trade Volume Activity in month of Shawwal 2021, in the Kolmogorov-Smirnov $\mathrm{Z}$ column, is 1.09 and for the Asymp column. Sig (2-tailed) 0.18. Is greater 0.05 (> 0.05); therefore, Trading Volume Activity for the month of Shawwal 2021 has met the assumption of normality, or the data has been normally distributed.

\subsection{Hypothesis Testing I}

Table 4.3. Hypothesis Test Results of AR

\begin{tabular}{|c|c|}
\hline Statistic & $\mathbf{2 0 2 1}$ \\
\hline $\mathrm{T}$ & -3.62 \\
\hline Df & 7.00 \\
\hline Sig. (2-tailed) & 0.01 \\
\hline Note & Significance \\
\hline
\end{tabular}

Table 4.3 shows that:

1. The value of the 2021 Abnormal Return t-test in the $t$ 
column is -3.62 and in the Sig column. (2-tailed) is 0.01, or below 0.05 . It confirms that Ho is rejected, meaning that there is significant different in AR before-after month of Ramadan for companies on Indonesia Stock Exchange in 2021. Value in column $t$ shows minus (-), which means that AR for the month of Sha'ban is greater than AR in the month of Shawwal. This finding is in line with that of Bash et al., (2019), showing that the changes in stock price exceeded the normal conditions, leading to abnormal returns. According to Kumar, A., Page, J. K., \& Spalt, (2011) the Ramadan Effect shows the abnormal return obtained by investors, and the market reaction can be measured by the presence of abnormal returns. The effect of Ramadan appeared in the volume of the transaction activities. The information stored by investors would make changes to the daily trading volume fluctuations and the frequency of transactions. This fluctuation is caused by some personal information displayed through the transaction process, not because of the spread that increases public information (Antoniou, C., Doukas, J.A., Subrahmanyam, 2013). This finding was in line with research results Pantzalis \& Ucar, (2014) that abnormal returns would interpret abnormal returns from securities that may occur before and after the announcement of an event. Excess revenue is the gain on actual revenue that occurs on normal returns. Therefore, the occurrence of abnormal returns is triggered by certain events.

\subsection{Hypothesis Testing II}

Table 4.4. Hypothesis Test Results of TVA

\begin{tabular}{|c|c|}
\hline Statistic & $\mathbf{2 0 2 1}$ \\
\hline $\mathrm{T}$ & 1,19 \\
\hline $\mathrm{Df}$ & 7.00 \\
\hline Sig. (2-tailed) & 0.27 \\
\hline Note & Not Significance \\
\hline
\end{tabular}

Table 4.2 shows that:

1. The value of the 2021 Trading Volume Activity t-test in the $t$ column is 1.19 and, in the Sig., (2-tailed) is 0.27 , or above 0.05 . It is confirmed that Ho was accepted, meaning there wasn't significant difference in TVA before and after Ramadan for company on Indonesia Stock Exchange in 2021. The finding was in line with the research by conducted Białkowski et al, (2013), Reilly, F. K., \& Brown, (2012), and Pantzalis \& Ucar, (2014), Basel, (2013), Mo et al., (2019), Kumar et al., (2011), Mustafa, (2011), showing that there is a difference in average return of exceptions before -after event. In line with research of Białkowski et al, (2012), regarding impact of certain events abnormal return and trading volume activities, study conducted using the events study method to observe market share prices at time of event to find out whether there was a return on investment received by investors. As a result, the investors could get unusual investment returns resulting from these events, the sensitivity level of capital market dynamics was influenced by macro factors, such as economic and non-economic factors.

\subsection{Descriptive Statistic}

Portrayals of factors utilized in this study are introduced in Table 4.1. It shows that normal market return is less $1.00 \%$. The low normal return in 2021 is expected to declining in execution of the capital business sectors as an aftereffect of ramadhan sway in the Indonesian. The standard deviation of data imbalance shows that there is a high instability of data imbalance information during 2021.

Return scattering as estimated by CSSD, CSAD, and $\gamma$ demonstrates that CSSD has a higher esteem than the others. This demonstrates that CSSD gives the greatest proportion of return scattering, while $\gamma$ is the littlest. This could be because of most of the middle worth of the normal day by day return is zero, so the worth of $\gamma$ will be shut to the normal worth return.

\subsection{Classical Assumption Test}

Traditional suspicion test found that the information utilized in this examination didn't meet nonautocorrelation presumptions. Nonetheless, the fixed test shows that the information utilized in this investigation are fixed. To beat the issue of autocorrelation, this examination changed factors by utilizing Cochrane Orcutt technique. In view of the change information, this examination didn't disregard the suspicion of autocorrelation and other old style presumptions. Also, this investigation avoided a few anomalies by eliminating perceptions that have a flat out studentized leftover worth more prominent than 3 likelihood under 0.001 .

\section{Conclusions and Suggestions}

\subsection{Conclusions}

1) Abnormal Returns (AR) is significantly different between before (Sya'ban)-after the month of Ramadan (Syawal) in companies on the Indonesia Stock Exchange 2021. Results indicate that AR reactions consistent the Ramadhan Effects.

2) Trading Volume Activities (TVA) doesn't differ significantly before (Sha'ban) and after month of Ramadan (Syawal) for companies on the Indonesia Stock Exchange in 2021.

\subsection{Suggestions}

1) It is recommended that further research should add the period of researching to accommodate variations between times can be observed more clearly. 
2) Further research would better add research variables to measure the reaction of the capital market, instead of having variables Abnormal Returns and Trading Volume Activities.

\section{For Academics}

For additional exploration, it is required to take a longer timeframe for a very long time so that the constancy of Ramadhan Effect can be analyzed and can also utilize the GARCH model to take out the presumption of heteroscedasticity.

\section{For Investors}

This examination has prevailed with regards to discovering an example of strange return developments of the subsector under study which comprised of IDX. Financial backers can take benefit or hold results by considering the developments of the aggregate strange return produced in this examination.

\section{Acknowledgment}

This article is the output of research funded by the DIPA fund of the Faculty of Economics and Business, Diponegoro University for the 2021 fiscal year.

\section{REFERENCES}

[1] O. G. Kumar, A., Page, J. K., \& Spalt, "Religious beliefs, gambling attitudes and financial market outcomes," $J$. financ. econ., vol. 102, no. 3, pp. 671-708, 2011.

[2] A. A. S. V. N. Robert, "Exchange Rates and Oil Prices," Rev. Int. Econ., vol. 6, no. 4, pp. 683-694, 2018.

[3] A. Nicola, M., Alsafi, Z., Sohrabi, C., Kerwan, A., \& Al-jabir, "The Socio-Economic Implications of the Coronavirus and COVID,” Int. J. Surg., 2021.

[4] K. C. Reilly, F. K., \& Brown, Analysis of investments and management of portfolios, 10th ed. 2012.

[5] F. Al-Mudhaf, "The Islamic calendar effects: Evidence from twelve stock markets," Int. Res. J. Financ. Econ., vol. 87, pp. 185-191, 2012.

[6] A. Bash, K. Alsaifi, and J. Khashoggi, "Journal of Behavioral and Experimental Finance Fear from uncertainty : An event study of Khashoggi and stock market returns," J. Behav. Exp. Financ., vol. 23, no. October 2018, pp. 54-58, 2019.

[7] A. Antoniou, C., Doukas, J.A., Subrahmanyam, "Cognitive dissonance sentiment and momentum," J. Financ. Quant. Anal., vol. 48, pp. 245-275, 2013.

[8] Blasco, N., Corredor, P., Ferreruela, S., "Market sentiment: a key factor of investors' imitative behaviour," Account. Financ., vol. 52, no. 3, pp. 663-689, 2012.
[9] Y. Baker, M.; Wirgler, J.; \& Yuan, "Global, Local, and Contagious Investor Sentiment," J. Appl. Financ. Econ., vol. 104, pp. 272-287, 2012.

[10] J. Białkowski, A. Etebari, and T. P. Wisniewski, "Fast profits: Investor sentiment and stock returns during Ramadan," J. Bank. Financ., vol. 36, no. 3, pp. 835-845, 2012.

[11] J. Białkowski, M. T. Bohl, P. Kaufmann, and T. P. Wisniewski, "Do mutual fund managers exploit the Ramadan anomaly? Evidence from Turkey," Emerg. Mark. Rev., vol. 15, pp. 211-232, 2013.

[12] M. S. M. Calomiris, C. W., Love, I., \& Peria, "Stock returns' sensitivities to crisis shocks: Evidence from developed and emerging markets," J. Int. Money Financ., vol. 31, no. 4, pp. 743-765, 2012

[13] B. J.-C. H. Y. S. Tantatape, "Crude oil prices and exchange rates: Causality, variance decomposition and impulse response," Energy Econ., vol. 44, pp. 407-412, 2014.

[14] B. T. K. Jozef, "Measuring the Frequency Dynamics of Financial Connectedness and Systemic Risk," J. Financ. Econom., vol. 16, no. 2, pp. 271-296, 2018.

[15] R. R. G. S. M. M. Aloui, "Uncertainty and crude oil returns," Energy Econ., vol. 55, pp. 92-100, 2016.

[16] K. Gavriilidis, V. Kallinterakis, and I. Tsalavoutas, "Investor mood, herding and the Ramadan effect," J. Econ. Behav. Organ., vol. 132, pp. 23-38, 2016.

[17] H. Al-Hajieh, K. Redhead, and T. Rodgers, "Investor sentiment and calendar anomaly effects: A case study of the impact of Ramadan on Islamic Middle Eastern markets," Res. Int. Bus. Financ., vol. 25, no. 3, pp. 345-356, 2011.

[18] N. S. S. Paresh Kumar, "New evidence on oil price and firm returns," J. Bank. Financ., vol. 35, no. 12, pp. 3253-3262, 2011.

[19] O. Al-Khazali, "Revisiting fast profit investor sentiment and stock returns during Ramadan," Int. Rev. Financ. Anal., vol. 33, pp. 158-170, 2014.

[20] A. R. Sonjaya and I. Wahyudi, "The Ramadan effect: Illusion or reality?," Arab Econ. Bus. J., vol. 11, no. 1, pp. 55-71, 2016.

[21] X. Mo, Z. Su, and L. Yin, "North American Journal of Economics and Finance Can the skewness of oil returns affect stock returns? Evidence from China's A-Share markets," North Am. J. Econ. Financ., vol. 50, no. August, p. 101042, 2019.

[22] A. Kumar, J. K. Page, and O. G. Spalt, "Religious beliefs, gambling attitudes, and financial market outcomes," $J$. financ. econ., vol. 102, no. 3, pp. 671-708, 2011.

[23] R. F. and M. R. Aguilera, "The synchronized and exceptional price performance of oil and gold: Explanations and prospects," Resour. Policy, vol. 54, pp. 81-87, 2017.

[24] Summers, B., Duxbury, D., "Decision-dependent emotions and behavioral anomalies," Organ. Behav. Humanit. Decis. Process, vol. 118, no. 2, pp. 226-238, 2012.

[25] A. \& P. Del Guidice, "The Impact of The Arab Saudi Spring and the Ebola Outbreak on African Equity Mutual Fund 
Investor Decisions," J. Int. Bus. Financ., vol. 41, pp. 600$612,2017$.

[26] Y. H. Y. F. J. \& C. L. J. Wang, “An Inventor's Perspecitve on Infectious Diseases and Their Influence on Market Behaviour," J. Bus. Econ. Manag., vol. 14, pp. 112-127, 2013.

[27] T. P. Białkowski, J., Etebari, A., \& Wisniewski, "Fast profits: Investor sentiment and stock returns during Ramadan," J. Bank. Financ., vol. 36, no. 3, pp. 835-845, 2012.

[28] M. S. M. Calomiris, C. W., Love, I., \& Peria, "Stock returns' sensitivities to crisis shocks: Evidence from developed and emerging markets," J. Int. Money Financ., vol. 31, no. 4, pp. $743-765,2012$

[29] L. Mo, X., Su, Z., \& Yin, "North American Journal of Economics and Finance Can the skewness of oil returns affect stock returns? Evidence from China's A-Share markets," North Am. J. Econ. Financ., vol. 50, no. August, p. 101042, 2019.
[30] A. Antoniou, C., Doukas, J.A., Subrahmanyam, "Cognitive dissonance sentiment and momentum," J. Financ. Quant. Anal., vol. 48, pp. 245-275, 2013.

[31] Summers, B., Duxbury, D., "Decision-dependent emotions and behavioral anomalies," Organ. Behav. Humanit. Decis. Process, vol. 118, no. 2, pp. 226-238, 2012.

[32] C. Pantzalis and E. Ucar, "Religious holidays, investor distraction, and earnings announcement effects," J. Bank. Financ., vol. 47, no. 1, pp. 102-117, 2014.

[33] A. A. I. M. Basel, "Dynamic spillovers between oil and stock markets in the Gulf Cooperation Council Countries," Energy Econ., vol. 36, pp. 28-42, 2013.

[34] K. Mustafa, "The Islamic calendar effect on Karachi stock market," Pakistani Bus. Rev., pp. 562-574, 2011.

[35] S. I. A. Afees A., "Gold as a hedge against oil shocks: Evidence from new datasets for oil shocks," Resour. Policy, vol. 66, pp. 101-606, 2021. 